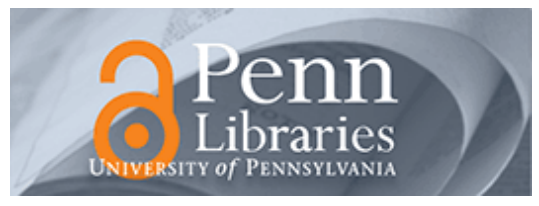

University of Pennsylvania

ScholarlyCommons

\title{
The Production of Relevant Scales: Social Identification of Migrants During Rapid Demographic Change in One American Town
}

Stanton Wortham

University of Pennsylvania, stanton.wortham@bc.edu

Catherine R. Rhodes

University of Pennsylvania, rhodesc@gse.upenn.edu

Follow this and additional works at: https://repository.upenn.edu/gse_pubs

Part of the Bilingual, Multilingual, and Multicultural Education Commons, and the Social and Cultural Anthropology Commons

\section{Recommended Citation}

Wortham, S., \& Rhodes, C. R. (2012). The Production of Relevant Scales: Social Identification of Migrants During Rapid Demographic Change in One American Town. Applied Linguistics Review, 3 (1), 75-99. http://dx.doi.org/10.1515/applirev-2012-0004 


\title{
The Production of Relevant Scales: Social Identification of Migrants During Rapid Demographic Change in One American Town
}

\begin{abstract}
This essay explores the question of relevant scale: which of the many potentially relevant processes from interactional through local through global, from nearly instantaneous through those emergent over months, years or centuries - in fact contributes to social identification in any given case, and how do these heterogeneous processes interrelate? Contemporary answers to this question have moved beyond the détente of the "micro-macro dialectic," in which purportedly homogeneous "macro" processes constrain events and actions, while being simultaneously constituted by "micro" events and actions. We review contemporary work on these issues, with particular reference to the use of language in social identification, and we argue that an adequate account must go beyond "micro" and "macro." We illustrate our argument with data from a seven-year ethnographic project in an American town that has received thousands of Mexican immigrants over the past decade, focusing on two types of narratives that residents tell about immigrants: stories about "payday muggings" in which immigrants are victimized, and stories about the town's historical trajectory and immigrants' role in it. These narratives emerge and move across different scales, and they are an important resource for residents as they socially identify themselves and others.
\end{abstract}

\section{Keywords}

timescale; social identification; micro-macro; migrants; narratives

\section{Disciplines}

Anthropology | Bilingual, Multilingual, and Multicultural Education | Education | Social and Cultural Anthropology 


\title{
The production of relevant scales: Social identification of migrants during rapid demographic change in one American town
}

\author{
STANTON WORTHAM and CATHERINE RHODES
}

Abstract

This essay explores the question of relevant scale: which of the many potentially relevant processes - from interactional through local through global, from nearly instantaneous through those emergent over months, years or centuries - in fact contributes to social identification in any given case, and how do these heterogeneous processes interrelate? Contemporary answers to this question have moved beyond the détente of the "micro-macro dialectic," in which purportedly homogeneous "macro" processes constrain events and actions, while being simultaneously constituted by "micro" events and actions. We review contemporary work on these issues, with particular reference to the use of language in social identification, and we argue that an adequate account must go beyond "micro" and "macro." We illustrate our argument with data from a seven-year ethnographic project in an American town that has received thousands of Mexican immigrants over the past decade, focusing on two types of narratives that residents tell about immigrants: stories about "payday muggings" in which immigrants are victimized, and stories about the town's historical trajectory and immigrants' role in it. These narratives emerge and move across different scales, and they are an important resource for residents as they socially identify themselves and others.

Keywords: timescale, social identification, micro-macro, migrants, narratives

Social identification is ubiquitous, happening at various scales as individuals and groups typify themselves and others. In our recent work we have been investigating the heterogeneous social identifications happening in an American community that has only recently included many immigrants from Mexico. These social identifications happen locally - when, for example, a person who 
has recently arrived from Mexico and speaks little English interacts with clerks in a store, negotiates with a potential employer or petitions government bureaucrats. Social identification also happens over somewhat longer timescales - when, for example, local school district policies position native Spanish speakers in certain ways, and when local newspaper editorials and letters to the editor contrast longstanding residents' family immigration histories with those of more recent Mexican immigrants. And social identification happens over larger spatial and temporal scales - when, for example, national media repeat politicians' demonization of undocumented immigrants, or when the Catholic Church welcomes Latin American immigrants to new locations by strategically assigning Spanish-speaking clergy.

All of these social identifications seem familiar and unproblematic. From a social scientific perspective, however, one might prefer a more elegant account to such a list of heterogeneous types of identification. Are certain underlying processes always relevant to social identification? How do processes at different scales relate to one another? For example, a local, "micro-level" interaction between an immigrant and his or her potential employer may be constrained by mass media that has brought "macro-level" anti-immigrant stereotypes to the attention of that employer. Many have pointed out the power that more spatially and temporally extensive processes have to constrain more local and shorter processes in this way. Others, however, have emphasized the emergence of unexpected patterns at shorter and more local scales. For example, that interaction between the employer and the potential employee might produce unexpected social identification when the employer discovers similarities between his Italian immigrant parents and the newly arrived Mexican immigrants, or when he learns he can speak Italian and be partly understood by many Mexicans. These two points, about the power of top-down constraint and the simultaneous importance of bottom-up emergence, have led many social scientists to adopt a common account: the "macro-micro dialectic." Over the past several decades this account has become popular in applied linguistics and applied anthropology, and it is easy to understand its appeal: Local actions are clearly constrained by broader processes, but local actors can also create unexpected patterns that sometimes change those broader processes.

In recent years, however, critics have begun to move beyond the macromicro dialectic. This essay describes some of the more important criticisms. Instead of imagining two allegedly homogeneous scales, more recent accounts ask which of the many potentially relevant processes - from interactional through local through global, from nearly instantaneous through those emergent over months, years or centuries - in fact contribute to social identification in a given case and how these heterogeneous processes interrelate. We review some contemporary formulations of these questions, with particular reference 
to the use of language in social life, and we follow contemporary critics in arguing that the field must go beyond "macro" and "micro."

\section{Marshall}

We explore these issues with reference to our work in an American town that has only recently become home to many Mexican immigrants. Marshall, a pseudonym, is a suburb with a population of about 35,000 that had 100 Mexican residents in 1990, 2,000 in 2000, and 8,000 in 2010 (U.S. Census Bureau, 2011). Mexicans went from representing less than one percent of the population in 1990 to over 22 percent in 2010.

Marshall is located in a large East Coast metropolitan area. The town's African American population began with some arrivals at the end of the $19^{\text {th }}$ century, but most Black residents or their ancestors arrived in the decades after World War II. Foreign-born immigrants also form an important part of Marshall's history. After its founding by English and German settlers two centuries ago, Irish immigrants arrived in the $19^{\text {th }}$ century, followed by two waves of Italian immigrants in the $20^{\text {th }}$ century. Smaller groups of Puerto Rican, South Asian and Caribbean newcomers settled in Marshall starting about forty years ago, though most have moved on by now. The population changed significantly between 1990 and 2010 - from 70\% White (non-Hispanic), 25\% African-American and 3\% Latino to 32\% White (non-Hispanic), 35\% AfricanAmerican, and 28\% Latino (the vast majority of these Latinos are Mexican). This rapid demographic change means that Marshall residents have more fluid views about Mexicans than one finds in national discourse and in areas of traditional Latino settlement. Because the Mexican population is so new in this location, both immigrants and longstanding residents have more flexibility in identifying each other (Wortham, Mortimer \& Allard, 2009).

When Mexican immigrants came to Marshall they disrupted a relatively stable ethnic landscape. One feature of this landscape was the presence of "blacks" and "whites," with familiar American racial stereotypes and struggles for power in town government and other institutions. Another feature was the division of the Catholic community between Irish and Italian-origin parishes, with Italians having arrived more recently than the Irish and feeling disempowered in some respects. Mexicans do not fit neatly into these familiar divisions. On the streets of Marshall, Mexicans are usually distinguishable by their use of Spanish and limited English, their physical appearance and the networks that brought them to the town. As more and more Mexicans live, work and go to school in Marshall, both longstanding residents and immigrants must socially identify them, asking and answering questions such as: What types of people 
are they? Why have they settled here? How do they relate to other groups in town? What will their role be in the town's future?

One longstanding white, non-Hispanic resident summarized the situation in an exchange with a white researcher, recorded in the following fieldnote:

In some ways they are looking more like the traditional immigrant trajectory: they're working their asses off, in low level, low wage jobs; but every restaurant, every kitchen all over town has busboys and kitchen staff who are Mexican. They used to be African American but now they're all Mexican. Also in landscaping and swimming pool maintenance. Everyone's noticing. The question is whether it's for purposes of moving up in the economy here or for a better life in Mexico. We see kids go home for Christmas and never come back, or miss several months of school.

How do speech events like the one described in this fieldnote, in which a longstanding white resident characterizes Mexican immigrants while speaking to a white researcher, add up to more widespread social identities that are assigned to and perhaps taken on by Mexican immigrants in this town?

Work in linguistic anthropology and sociolinguistics - and the broader fields of anthropology and sociology - often answers this question in terms of the "macro-micro dialectic," an approach often credited to Giddens (1976). Analysts posit "macro" structural or institutional processes in order to explain a local phenomenon like the social identification of Mexican immigrants in Marshall. That is, people like the resident in the fieldnote above are constrained in their beliefs and behaviors by widespread models and habits. For example, immigrants around the world are often construed as either "good" or "bad," with the former allegedly following a cross-generational, upwardly-mobile immigrant trajectory and accepting existing socioeconomic patterns, while the latter challenge these patterns (Suárez-Orozco, 1998). This widely circulating model may be presupposed in the passage above, which characterizes Mexicans both as upwardly-mobile immigrants and as transient migrants who squander educational opportunities. At the same time, analysts argue that "micro" actions and interactions constitute the structural and institutional processes that provide essential context to those actions. Broader models and habits are constituted by concrete instances of identification, as when this Marshall resident socially identifies Mexican immigrants in the passage above. More widely circulating models of immigrant identity only exist in particular events like this one, and the details of contingent events can inflect or even transform broader models. The speaker above tailors his comments to the case of immigrants who happen to be from a neighboring country and can thus more easily go home, for instance, lamenting how this robs their children of the opportunities allegedly afforded by American schooling. Perhaps in a more globalized world with increasing bi-directional movement the models of "good" and "bad immigrant" will shift, as particular events like this one con- 
textualize the models in changing ways. In the full "macro-micro dialectic," both macro and micro play an important role: macro processes constrain and micro processes constitute, simultaneously.

\section{Beyond micro and macro}

It has become increasingly clear that such an account cannot suffice (Wortham, in press). Under scrutiny, neither "macro" nor "micro" - nor the related concepts "structure" and "agency" - constitutes a coherent level of explanation, and simply combining them does not solve the problem. Microanalysts' emphasis on the unexpected patterns that can sometimes disrupt stable sociocultural practices and expectations did play an important role in overcoming earlier deterministic accounts (e.g., Bowles \& Gintis, 1977). Practices change and people develop new ways of understanding their experiences, and a focus on the micro has usefully highlighted this. Adequate accounts of social identification and other central human processes must account for the emergence of unexpected models and behaviors. As long as this insight about contingent emergence is not taken to mean that more extensive patterns have no coercive power, it is central to any adequate account of social identification. But if we construe emergence as necessarily springing either from the "agency" of individual actors or from "micro" interactional improvisation, we misunderstand it. Unexpected patterns emerge at various scales and are not limited to individual actions or discrete events.

The concept of "agency" usually presupposes misleading assumptions from the Enlightenment - about autonomous rational minds, about the individual as the relevant level of analysis for meaningful phenomena, about the dignity and the fundamental isolation of individuals. "Agency" in this sense cannot explain the emergence of most unexpected patterns. Individuals do sometimes develop their own plans for novel actions, of course, and they sometimes put these into effect and thereby change larger social patterns, although such action is always mediated through resources borrowed from the collective. Emergent patterns, however, are more often accomplished by groups. Sometimes this happens at the interactional level, when interlocutors create an unexpected response through improvisation (Schegloff, 2007; Sawyer, 2003). It can also happen among groups over longer scales, as when a family or a workgroup engages in what Shotter (1993) calls "joint action" - actions that cannot be reduced to the contributions of any individual. These actions sometimes occur within discrete events, but they also occur across events. A couple can work on a new form of relating, for example, over months or years, and the emergence of this pattern is not typically reducible either to the single action of an individual or to discrete events. A team or system that includes both humans and 
tools can develop new forms of problem-solving, for instance, such that analysts must attend to an interrelated set of dispositions and actions, together with non-human contributions, as the relevant level of analysis for explaining change (Latour, 2005; Michel \& Wortham, 2009). The town of Marshall contains various local emergent processes that might influence the social identification of Mexican immigrants there - like the emergent interethnic relationships between Italian Americans and Mexican immigrants, which cannot be reduced to "structural" patterns that extend beyond the town but are not reducible to individual actions or events either. In explaining emergent phenomena like the social identities inhabitable by Mexicans in Marshall, we must figure out what level of analysis is appropriate. If we decide ahead of time that either individual agency or creativity within discrete interactions is the privileged level for explaining emergence, we will misunderstand cases that are better explained with reference to other scales (Bateson, 1972).

Those who emphasize the "macro" side of the "macro-micro dialectic" are correct that constraint plays as important a role in social identification as emergence. Silverstein (1992) and others have shown that microanalysis itself relies on enduring patterns. Signs are polysemous, and disambiguation only occurs as participants presuppose models and habits that extend beyond the speech event. However, just as microanalysts often explain their insight about emergence with reference to one homogeneous factor like "agency" or interactional creativity, macroanalysts, too, often explain their insight about constraint with reference to "structure," as if this implies a homogeneous level of organization. But "structure" is in fact used to refer to heterogeneous practices and models, such as those ranging from capitalist practices of exchange that have emerged over millennia, to colonialist practices that have taken place across centuries, to the accelerated movement of people and ideas around the globe that has occurred over the past few decades, to the emergence of new styles that take hold and pass away in a few years. We should not assume that these potential constraints are essentially similar. Any process that takes place at a longer or more extensive scale can constrain processes at shorter scales (Lemke, 2000). A novel presupposition that becomes established over a few seconds of interactional time can constrain the action of a subsequent speaker - even though we do not normally think of transient interactional accomplishments as "structure," and certainly not as the same type of structure as enduring institutional or ideological constraints. Constraints can also emerge from local, less enduring patterns that mediate or even undermine more enduring regularities. An unusual way of organizing gender relations in a classroom, developed across months of interaction among teachers and students, for example, can constrain participants' understandings of individual identities while nonetheless working against the typical gender relations more commonly found in the larger society (Wortham, 2006). 
In Marshall, local patterns are as important as "macro" ones in affording and constraining the social identities that Mexicans tend to inhabit. The fact that this town had two relatively large waves of Italian immigrants over the past century is important, because Italian-origin people in town feel some affinities with Mexican immigrants and respond to them more positively than do "white" residents with more distant immigrant histories. The contingent, local fact that Mexican immigrants began settling with their families in Marshall and having children about 10 years ago is also important. Other towns that experienced earlier or later surges of Mexican schoolchildren are at different points in their development of a bilingual population of schoolchildren, one whose educational prospects differ from their siblings who entered American schools at older ages or who went directly to work.

The heterogeneity of such constraining factors means that terms like "macro" and "structure" are potentially misleading. Constraint is crucial to any adequate account of social identification, but we should not imagine that it is a homogeneous process grounded in one level of explanation. Many different types of ideas and practices can constrain, in various ways. Constraints can support or undermine each other, and many different kinds can operate in any given case. Sometimes a crucial constraint is institutionalized in longstanding practices, but at other times institutions play only minor roles in establishing an effective constraint. Sometimes constraints are established by a small group and remain unrecognized or irrelevant to most people, but this does not change their power to limit choices and direct action within that group. Sometimes constraints are ephemeral, as when presuppositions take hold then disappear quickly in an interaction or a passing fad, instead of being based in longstanding ideas and practices. Instead of assuming that a given macro structure or institutional process normally plays the crucial role in constraining thought and action, we must investigate the types of constraint actually influencing our objects of study in specific instances.

We thus make similar claims about "macro" and "micro" analyses. These terms are useful insofar as they draw attention to processes of emergence and constraint essential to explaining social identification and other important human processes. But the terms are misleading insofar as they focus attention on allegedly homogeneous levels of explanation - individual creativity or interactional improvisation, on the one hand, and widespread ideologies or institutionalized practices on the other. In fact, both emergence and constraint are accomplished at various scales. Our job as analysts is to identify the types of emergence and constraint relevant to a focal phenomenon or process. These relevant processes will vary from case to case, and some will be neither "macro" nor "micro." Later in this article, we sketch how such an analysis might proceed, drawing on data from Marshall. Due to limited space, however, the analysis will be incomplete. Readers can consult other work on the town 
for more details (e.g., Wortham, Mortimer \& Allard, 2009; Mortimer, Wortham \& Allard, 2010; Wortham, Mortimer, Lee, Allard \& White, 2011; Wortham, Mortimer \& Allard, 2011).

\section{Beyond the speech event}

Linguistic anthropology and sociolinguistics have traditionally focused on the speech event as the focal unit of analysis (Hymes, 1964). Some have studied typical speech events, describing how certain events recur among and characterize a group of speakers or social locations (Heath, 1983; Philips, 1983; Schieffelin \& Ochs, 1986). Others have focused on the emergence of events over interactional time, as interlocutors enact sometimes-unexpected patterns (Duranti \& Goodwin, 1992; Erickson \& Shultz, 1982; Ochs, Schegloff \& Thompson, 1996). Both types of speech event-focused work fit a "macromicro dialectic" paradigm, with typical events supporting generalizations about the macro and interactional work exemplifying the micro. More recently, however, linguistic anthropologists have begun to look beyond the speech event, studying the cross-event chains or trajectories required to explain social identification, cultural change and ontogenesis (Agha \& Wortham, 2005).

Agha (2007) argues that all cultural models linking signs with typifications of people and events have a "domain." They are recognized by only a subset of any community, and this subset changes as signs and models move and change across space and time. Any individual has a heterogeneous "repertoire" that overlaps with but also differs to some extent from members of the same community (Rymes, 2011). There is no one "macro" set of models or ideologies, universal to a group. Instead, there are models that move across domains, ranging from pairs, to local groups, all the way up to global language communities. In analyzing language and social life, we must describe various relevant resources - models drawn from different spatial and temporal scales - that facilitate a phenomenon of interest, and we must describe how models move across events (Agha, 2007; Agha \& Wortham, 2005; Wortham, 2005; Wortham 2006). Instead of focusing only on speech events, or simply connecting microlevel events to macro-level structures, we must investigate heterogeneous domains and the various scales of social organization relevant to understanding meaningful social action in any given case.

In Marshall, one set of divergent domains centers around high school and elementary school teachers (Link, Lipinoga, Allard, Wortham \& Mortimer, in press). Thus far in the history of Mexicans in Marshall, high school teachers work mostly with Mexican students who have come to the U.S. as older children and who are learning English. They often identify these students in ways 
familiar from other work on immigrant schoolchildren: as speaking limited English, as only interested in English for the sake of getting a job, as unlikely to succeed in school (van Dijk, 1987). But elementary school teachers have many children who have been born in the U.S. or who came here at young ages. Elementary teachers tell us that these children either already speak English or learn it rapidly. Our research shows that elementary teachers are much more likely to encourage bilingualism, incorporate Spanish into lessons and expect their Mexican students to succeed in school (Link, Lipinoga, Allard, Wortham \& Mortimer, in press). Within the demographically homogeneous group of white, young monolingual (English-speaking) female teachers in Marshall schools, then, we find two distinct models of identity for Mexican students. The more pessimistic high school teachers borrow from widely circulating models of unsuccessful immigrant students readily available in national media. The elementary school teachers borrow from widely circulating models of successful assimilation by earlier waves of immigrants to Marshall - models that are less often associated with Mexicans in U.S. national discourse at this historical moment. We must attend to the more local scale of Marshall as a town and the divergent groups of educators within this town in order to develop an accurate picture of how Mexican immigrant students are being identified. We must also attend to historical change, as this pattern of social identification will likely shift once today's (bilingual) Mexican elementary school students reach high school.

Other recent work in linguistic anthropology has followed Agha's emphasis on the movement of signs and associated models of identity over time, at different scales, tracing the emergence of models of identity as they become more widespread and constrain actions and interpretations. Rogers (2003), for instance, follows an individual American student's trajectory across two years, as the student and her family negotiate with authorities about whether she is "disabled." Rogers shows how both institutionalized and local models and practices facilitate the ontogenetic transformation of this student from being "low achieving" to being "disabled," and she follows the links among official texts, conferences, tests, family conversations and other events that constitute this student's movement toward disability. Wortham (2006) describes monthslong trajectories across which individual students' identities emerge in a ninth grade, urban American classroom. He traces the development of local models of identity that students come to occupy in this classroom, highlighting the distinctive gendered models that emerge. These local models both draw on and transform more widely circulating ones, and they are used in sometimesunexpected ways in particular classroom events. The analysis follows two students across the academic year, showing how they are socially identified in increasingly robust ways as speakers transform widely circulating models of race and gender into distinctive local models of appropriate and inappropriate 
studenthood, and as teachers and students contest these social identifications in particular interactions.

The concepts of "social domain" and "trajectories" describe how sociocultural regularities have variable extents. Given this fact, idealizations like homogeneous "speech communities" and social "structures" are often misleading abstractions. Once we begin to examine the heterogeneity of sociocultural processes and how they are always in motion (Urban, 2001), we see that "macro" and "micro" are abstracted away from a much larger set of what Lemke (2000) calls "timescales." A timescale is the characteristic spatiotemporal envelope within which a process happens. For instance, the emergence and development of capitalism, a process that in some respects has taken millennia, and in other respects centuries (Postone, 1993), is occurring across a very long timescale. In contrast, individuals develop their capacities and live their lives at ontogenetic timescales, across decades, drawing on but also developing sometimesunique versions of more widely circulating models and categories. There are also "local" patterns, which can develop over days, months and years. Teachers and students in a classroom over an academic year, for example, establish shared models and habits that draw on but can also be unique versions of more broadly circulating models and habits. And events take place at even shorter timescales, taking minutes or hours and sometimes involving unpredictable "microgenetic" patterns. There are also other timescales around and between "social-historical," "ontogenetic," "local" and "microgenetic," forming a continuum of timescales relevant for describing the human and natural worlds ranging from processes that characteristically take fractions of a second to those that take thousands of years.

Once we move beyond the sometimes useful but also often misleading idealizations of "macro" and "micro," however, we face a challenge. In order to explain complex phenomena like the social identification of individuals or groups, we must attend to a configuration of interconnected processes across several timescales. To focus on one or two timescales alone would be to misconstrue the heterogeneous resources that make social identification and other processes possible. Different focal phenomena must be explained with different configurations of relevant scales. We cannot establish in advance which resources and scales will be relevant to explaining any given phenomenon, and relevant timescales will vary from phenomenon to phenomenon. If an analyst could really know that it is always interactional virtuosity and capitalism, or individual agency and race, that constitute crucial features of the human world, we would know where to look for our explanations. But if resources and constraints can come from an indefinitely large set of potentially relevant scales, how do we know where to look to make sense of any given case?

Lempert (in press) argues that relevant scales are produced. The world does not contain a set of pre-established processes, at characteristic scales. Instead, 
processes become relevant to a given phenomenon as people in the setting engage in what he calls "scaling practices," practices through which heterogeneous resources from various scales are mobilized to constitute some focal object or process. In the case of Marshall, then, our task is to identify the central practices through which people mobilize resources to identify Mexican immigrants. What resources are central to the emerging social identities that are becoming available to characterize Mexicans in this town? Through what practices do these resources become available?

In the following sections we focus on narrative practices, which residents use to circulate models of immigrant identity within and across groups. Anthropologists have begun to explore the mechanisms through which models of identity move, including media, educational institutions, folklore and other oral practices (Agha, 2007; Agha \& Wortham, 2005; Spitulnik, 1996; Urban, 1996, 2001; Wortham, 2006). Storytelling is one such mechanism, as models of identity are used to characterize people in a storytelling event and then retellings of that story move the models across space and time. Narratives are one powerful means for communicating models of identity (Bakhtin, 1935/1981; DeFina, Schiffrin \& Bamberg, 2006; Wortham, 2001). Recurring narratives are one mechanism through which relatively stable models of identity can emerge and become robustly associated with particular groups (Krupa, 2009; Wertsch, 2002). Sometimes recontextualizations of a story mobilize different resources, as the story moves over time or from group to group. We focus on the "entextualization" (Silverstein, 1992) and "enregisterment" (Agha, 2007) that occurs when signs of identity and the models of personhood that they index become durably associated with some group. Models can become provisionally stabilized in this way across interactional, ontogenetic or historical time, as stories move across contexts and allow a model of identity to become taken for granted by some group, for some period of time.

In the rest of this article we follow two types of narratives across communities in Marshall: payday mugging stories and narratives of town history. Both types of stories are widespread in town, and both are used to identify Mexican immigrants. These narratives draw on models of Mexican immigrant identity that circulate more widely across the U.S., but they do not simply assign prestructured "macro" models to Mexicans in Marshall. As these broader models move into town, they are inflected by more local considerations. The narratives are also contextualized in concrete events, where narrators and audience members sometimes create unexpected characterizations of Mexican immigrants. These "micro" positionings, however, only take hold as stories move across trajectories of events, as new narrators take them up and as aspects of the tellings become more stable. The telling of the stories themselves makes certain resources and processes relevant to identifying Mexican immigrants. We 
follow the narratives through town, exploring how characterizations of Mexicans emerge across storytelling events.

\section{Payday mugging narratives in Marshall}

In their descriptions of immigrants and the demographic changes occurring in their community, many Marshall residents tell stories about "payday muggings." Narrators describe a Mexican victim who carries cash, because he is undocumented and cannot open a bank account, and the African American criminals who mug him. Police and community leaders claim that such muggings have declined in recent years, because banks have arranged to accept Mexican identification cards and thus allow undocumented immigrants to hold bank accounts. Payday mugging stories are nonetheless commonly told by white and Mexican narrators. Many of these stories undoubtedly narrate actual events. However, because the telling of the stories is so common - even with a decline in muggings and the reality that most narrators do not actually know anyone who has experienced a mugging - we argue that payday mugging stories help Marshall residents make sense of each other at a time of rapid demographic change. They do so by making various resources available to identify Mexican immigrants and other residents.

In an extended analysis of payday mugging narratives in Marshall, Wortham, Allard, Lee \& Mortimer (2011) argue that these move along two trajectories. Both trajectories start with the crime event itself. In the first trajectory, the police file a report. Subsequently, police officers speak with community members about the crime or reporters read the police reports and write stories about them. White and black residents then read newspaper articles about the incident and repeat the story among themselves. In the second trajectory, the victim, a Mexican immigrant, tells the story to family and friends, and Mexican immigrants speak about it among themselves. Mexican narrators also tell the story to people outside of the Mexican immigrant community, like teachers, clergy and researchers. These outsiders then repeat the story among themselves and in discussions with others in town. We do not claim that these are the only pathways along which payday mugging narratives move, but they provide a useful summary. Our question becomes: As they move from teller to teller, how do these stories draw on heterogeneous scales and make certain resources salient for socially identifying Mexican immigrants?

The following fieldnote provides an example of a payday mugging narrative from the first trajectory, in which a white policeman speaks with a white researcher:

There is a lot of African American crime on Latinos. Latinos don't have social security cards so they can't get bank accounts and have to take their money with them wherever 
they go. "They know you're out there with money." It's "like lions on lambs. Four to five African Americans on one Mexican." I ask if the crimes generally turn violent and he says, yes, very violent.

Like almost all other narrators, this policeman identifies the perpetrators as African American. Like many other narrators, especially whites and Mexicans, he characterizes the perpetrators as violent and predatory. Two-thirds of all narrators in our data mention that the perpetrators of payday muggings are African American, and many white and Mexican narrators voice these perpetrators as dangerous and violent. These stereotypes of African American males are widespread in American media and popular discourse, having been established over centuries. In contrast to this voicing of African Americans, the policeman characterizes the Mexican victims as passive, as victimized and as outnumbered - as "lambs."

This story, like many others told by white narrators, shows several characteristic features of payday mugging narratives in the first chain. White (and sometimes black) narrators describe how a lack of bank accounts and a lack of documentation make Mexicans vulnerable to payday muggings and reticent to report the crimes. This detail about documentation and bank accounts appears in most payday mugging stories told by whites, but it never appears in the stories told by Mexicans. White narrators in particular also describe Mexican victims as passive, "easy prey" who "get taken advantage of" and who do not want to involve the police because they are "afraid something would happen" to them. This version of the story presents Mexicans as passive and victimized, echoing the stereotypical voicing of Mexicans as gullible and submissive (DeGenova and Ramos-Zayas, 2003). This more widely circulating model becomes relevant to identifying Mexicans as the payday mugging stories spread among white residents and make the model salient.

However, as payday mugging stories move into the black community, they change. Black narrators do tell stories about payday muggings, although they typically have to be prompted to do so, but they characterize the perpetrators and victims differently.

Narrator: And uh, it's always the first of the month every week. Wait for all the people to go in the bank, get money, come out, they rob them. There's a lot of that.

Interviewer: Oh, okay. And who was doing that?

N: Well, everybody. Blacks, Mexicans, whites, you know, whoever needs the money.

I: $\quad$ So they're all-

N: $\quad$ So they're all doing it.

I: $\quad$ So they're mugging each other? So the blacks mugging- 
N: $\quad$ Mugging each other. The Mexicans taking their money. The whites, you know, I guess they figured well you take my money, I'm going to take his.

This working-class African American repeats the claim that payday is the stimulus for such muggings. But he describes the perpetrators as being of all races - black, Mexican and white. He also gives an explicit explanation of the perpetrators' motivation: They need the money.

As payday mugging stories move along a chain from witnesses and the police through newspapers and word of mouth into white and black communities, they have some common features. Many white and black narrators mention undocumented immigrants' lack of access to banks and the subsequent need to carry large amounts of cash. Almost all narrators characterize Mexican victims as passive, as "lambs" who get taken advantage of and who do not want the police to help them seek retribution. White narrators characterize black perpetrators as predatory and often violent. Black narrators, however, present the perpetrators as a small subset of their community motivated by drugs or need, as equal-opportunity muggers who target any victims with money. Black narrators do not racialize all blacks as violent and dangerous. They either distinguish a small set of "underclass" blacks (sometimes also including whites and Latinos) responsible for the crimes, or they do not racialize the perpetrators at all. Nor do black narrators emphasize Mexicans' passivity and victimhood in the same way as white narrators. We need to follow stories across settings like this, in order to see how the changing voicing and evaluation across narrators provides different resources for the social identification of Mexican immigrants. Different narrators use their stories to make different configurations of resources, from various scales, relevant to the projected identifications of Mexicans.

The second trajectory of payday mugging narratives begins with the Mexican victim and moves into the Mexican community. A group of Mexican women tell the following story:

D: Como si una persona va caminando en la calle y es mexicano, a lo mejor, lo asaltan, le

[sacan su dinero, les pegan

C: $\quad$ Oh sí, le pegan, por ejemplo, ah, un cuñado que tengo acá, iba caminando por la calle Main. Eran chamaquillos o sea muchachillos, de doce o catorce años

D: nada más iba caminando

C: y no más de pronto ellos empezaron a pegar a él. O sea sin [motivo sin Interviewer: $[$ ¿Por el din $=$

C: $\quad[=$ no, no, no

D: $[=$ no, nada, porque era mexicano 
C: cuando él quiso reaccionar con, por, por defenderse, empezaron a correr

I: $\quad$ Y pasa frecuente $=$

C: =Frecuentemente. He oído que, a otras personas también pasa frecuentemente

D: If a Mexican person walks in the street, maybe they assault him, take his money, hit him

C: yes, they hit him, for example, a brother-in-law that I have here, he was walking on Main Street. They were little kids, little boys, 12 or 13 years old

D: he was just out walking

$C$ : and suddenly they began to hit him, for no reason

I: For mon-...?

C: no, no, no

D: no, not at all, because he was Mexican

C: when he tried to react, to defend himself, they began to run away

I: And that happens frequent-... ?

C: Frequently. I've heard that it often happens to others too.

These women describe unprovoked and sudden violence on the part of muggers, who are understood to be African American because the women were talking about relations between African Americans and Mexicans in this conversation. The African American criminals are characterized as violent and unpredictable despite their young age. Other female Mexican narrators in this group emphasize the capriciousness of the attacks, even though they often involve robbery: He was attacked just because he is Mexican, not even for money.

The voicing of African American criminals in Mexican narrators' payday mugging stories is similar to the (violent and dangerous) voicing used by white narrators - perhaps in part because most Mexicans have been exposed to American media that portray African American males as dangerous. But many Mexican narrators do not characterize Mexican victims in the same way as white or black narrators. Instead of voicing Mexicans as passive victims, Mexican narrators describe some Mexicans as defending themselves. The following narratives were recorded during an informal conversation among several male Mexican high school students, a Spanish-speaking teacher and a Spanish-speaking researcher:

Student 1: ... como yo en Marshall veo que hay muchos morenos que venden drogas, hacen lo que quieren, que andan, andan robando a los- a los Mexicanos

... like I see in Marshall that there are a lot of blacks who sell drugs, do whatever they want, who go around, go around robbing Mexicans 
Teacher: ¿Por qué?

Why?

Student 3: Por simple gusto

For the simple pleasure of it

These young Mexican men describe African American criminals in ways familiar from other narratives, as victimizing others and as unpredictable. Blacks, in Mexican narrators' characterizations, hang around, sell drugs, steal, and are violent and sadistic. These narrators also characterize Blacks as not working hard and as resenting hardworking Mexicans. But they change the voicing of some Mexican victims from passive to active:

S1: No no no lo que pasa es que, okay, no a los chavos, no, porque a los yambos saben defenderse y todo; me entiende, pero casi más siempre lo agarran los-

S?: $\quad$ Los (tíos)

S1: Con lo, aha, (agreden casi a la mayoria) pero a los señores más grandes, cuando recíen recibe su cheque y todo eso, como an example, este- uno de mis amigos que vive en mi casa la otra vez casi le cortan la oreja. ¿Por qué? Porque le quería- lo querían asaltar y-

S?: $\quad$ That's not good, you know?

S1: y luego Okay, ya sabemos que nosotros cuando nos ven por la calle, si va uno o dos nos van a agarrar, ¿me entiendes? so nosotros tenemos que andar trayendo algo como knives, gun o something like that para defendernos, you know? It's not- it's not good porque ellos luego take guns and everything so I mean

S1: No no no what happens- not to the young guys no because the young guys know how to defend themselves and all, you understand, but almost more often they grab the

S?: $\quad$ The (older guys)

S1: With the, uhuh, (they assault almost the majority) but the older guys, when they've just received their check and all that, for an example thisone of my friends who lives in my house the other day, they almost cut off his ear. Why? Because they wanted to assault him and-

S?: $\quad$ That's not good, you know?

S1: and then Okay, we already know that we when they see us on the street, if it's one or two of us they are going to grab us, you understand me? So we have to walk around carrying something like knives, gun or something like that to defend ourselves, you know? It's not-it's not good because then they take guns and everything so I mean

These young men describe "older guys" as the victims of the payday muggings, but not young men who would defend themselves against violent pay- 
day muggers. This voicing of Mexicans as assertive contrasts sharply with the characterization given by white and black narrators. Many Mexican male youths, at least, dispute the characterization of Mexicans as submissive and easily victimized; they resist the gendered aspect of payday mugging narratives that place male Mexicans in a passive, vulnerable role that threatens their masculinity. As these young men recontextualize the narratives, they make models of gendered identity relevant to the social identification of Mexicans in Marshall.

Further down this second trajectory of storytelling events, Mexican residents speak with people outside of their community about payday muggings, and these hearers go on to retell the stories among themselves. Thus the stories enter public discourse in the white and black communities and intersect with versions that came down the first trajectory. Payday mugging stories told by white teachers and white (or longstanding resident Latino) service professionals differ from those told by Mexican narrators in three ways: They often include reference to bank accounts and Mexicans' illegal status as an explanation for the events; they sometimes make specific reference to "gangs" and the potential for racial tension to escalate beyond these muggings; and they cast Mexicans as passive victims instead of as people who might actively defend themselves. Either because white narrators change the stories that they heard from Mexicans, or because they combine these stories with versions that they read in the newspaper or hear in town, the stories in the second chain change as they leave the Mexican community. The Mexican victim in the story changes from active to passive, and the racial tension goes from a conflict over specific issues - like jobs and housing - to a general dread about gangs and eruptions of violence. This aspect of many white narrators' stories mobilizes resources from models of predatory, disaffected youth.

By following payday mugging stories as narrators in different communities recontextualize and change them, we can see speakers who belong to different social domains presupposing different models of identity for Mexican immigrants in town. When the stories enter the black community, victims become more generic: Their Mexicanness is not relevant, and they are portrayed as less sympathetic than the victims in white or Mexican tellings. Perpetrators also become just one segment of the community, most often young drug dealers and not churchgoing or professional blacks like the narrators. When the stories move from Mexican youth to white teachers, Mexican victims shift from active to passive, their undocumented status is foregrounded and racial tension becomes more about "gangs" and less about interethnic resentment. By following these payday mugging narratives as they move across space and time, we can see different voices assigned to immigrants and different evaluative positioning across narrators. Some of this aligns with and draws on widely circulating models of identity, as the narratives make larger scale resources available. 
But other patterns draw on more local stances and ideas, like the aggressive positioning of some young Mexican men. This latter pattern may be changing with the historical shift from Mexican youth who have come to the U.S. as adolescents to those who have grown up in the U.S., as members of the latter group begin to position themselves differently with respect to both whites and blacks.

Narratives, then, can carry models of identity, serving as a vehicle through which people conceptualize and communicate their characterizations and evaluations of people like Mexican immigrants in Marshall. But narratives do not merely presuppose "macro" models of identity and/or transform these models in "micro" events. Payday mugging narratives draw on some intermediate scale models, like young Mexican males' accounts of themselves as aggressive, which contradict more widely circulating ones. And narrating events are linked together in trajectories, which collectively characterize groups of people in ways that cannot be reduced to discrete speech events. We must follow these narratives over time, across speakers, to capture how they contribute to social identification in this community.

\section{Narratives of town history in Marshall}

Marshall residents tell other kinds of stories that characterize and evaluate Mexican immigrants, and these stories also make available resources from various scales. We examine one other type of narrative told across different groups in town: stories of the town's history and future, including the role of Mexican immigrants in the town's historical trajectory. Mexicans now figure prominently in Marshall residents' stories about their town, and immigrants are characterized in various ways through these stories. Many narratives compare Mexicans to past immigrants, especially to Italians. As we follow these narratives over time, we see narrators from different groups sharing some characterizations while changing others to fit their own models and the changing historical circumstances.

We have been collecting data in Marshall since 2004. When we began, the conversation described on p. 78 (which occurred in 2005) was typical. Like many others, this longstanding Marshall resident wondered whether the new immigrants were here to stay in Marshall, such that they would join the local community, or whether they planned to return to Mexico after making some money. For most of the $20^{\text {th }}$ Century, many Mexicans came to the U.S. as migrant workers. They worked, sent money home, and most eventually returned to families that they had left behind in Mexico. As one local resident described it: "They send all of their money back and then eventually they would go back. 
So, they come, make a lot of money and then go back. They were transient, they didn't stay. And maybe, if they came back again, maybe they didn't come to Marshall. . . . They'd go somewhere else." As they are voiced in this story, transient Mexicans will not be a long-term asset or concern for the town, because they are not rooted there. This makes the assimilation experiences of earlier waves of European immigrants irrelevant to identifying Mexicans in contemporary America.

It is likely that longstanding residents' stories about the future of Mexicans in their community were influenced by Mexicans' own narratives. In the early years of our fieldwork, immigrants generally claimed that they had come to the U.S. to work and that they planned to return to Mexico. These stories have remained consistent over the past seven years. Mexicans in Marshall continue to tell a story of their plans to return to Mexico, and one of the most frequently cited reasons for returning is the pain of separation from their families. Mexicans also cite other reasons for returning: They miss foods and cultural practices, and they want to live in a safer environment, one more closely aligned with their moral values. One Mexican narrator reported that his father found his niece "doing inappropriate things," and so he plans to move the family back to Mexico. Another reported that it is not safe for Mexicans in Marshall because African American people attack them. Young immigrants also cite the opportunity to pursue post-secondary education, which is often not an option for undocumented youth in the U.S. Some immigrants also mention being understood and being able to speak Spanish as important factors. Most Mexicans' journeys to the U.S. began with a plan to return to Mexico - coming to the U.S. was a means to an end - and they plan to work toward buying a house in Mexico, furnishing their house, feeding a family left behind, or some other motive. Returning to Mexico would make their journey complete. Staying in the U.S. would represent a rupture in that trajectory.

For all these reasons, a large majority of Mexican immigrants continue to tell stories of their time in Marshall that end with people like them returning home. There is a puzzle in our data, however: white residents' stories about Mexicans' future in town have changed over the past several years, while Mexicans' have not. Mexicans have consistently narrated their return to Mexico, and whites used to tell stories like this also. But over the past five years Anglos' stories have shifted, such that now they most often describe Mexicans settling in town for the long term. This shift makes different resources available to identify Mexicans in Marshall, and it also positions white and Mexican narrators differently.

The change in Anglos' stories reflects a demographic reality. In Marshall, and around the country, a shift has been occurring in Mexican communities. There are fewer single men and more families, especially young families with children. As one longstanding resident said: "I had heard this before that this 
was a transient town, and people don't understand that. People think Mexicans are going to leave. Everyone else left. The Dominicans, the Puerto Ricans, the Nigerians [i.e., most earlier immigrants to Marshall]. They all left. But the Mexicans are not leaving because they have businesses. When people come to terms with that, it will be better." What used to be a community of Mexican migrants is becoming a community of families that have settled in Marshall, established businesses, become members of churches and brought immediate and extended family members to live with them. This shift has made it more difficult for undocumented Mexicans to cross the border, because crossing is more easily done by a single individual than by a whole family. Coupled with the general increase in the difficulty and cost of border crossing, and because of increased border enforcement, many Mexican families have settled more permanently in the U.S. (Massey \& Sánchez, 2010; Pew Hispanic Center, 2011).

Some longstanding residents recognize that Mexicans themselves still plan to return. As one said, "In the Mexicans' minds, they are not here to stay - they just want to make as much money as they can before they go back." Many white narrators argue quite explicitly that Mexicans do not believe that Marshall is "home." For Mexicans, Mexico is home, and they continue to believe that they will eventually return there. However, longstanding residents (accurately, in our view) perceive a shift in Mexicans' behavior - that is, despite the fact that Mexicans continue to say that they will return to Mexico, they are actually staying in the U.S. and are likely to do so long term. For example, one white narrator argues that, once Mexicans have been in the U.S. for an extended period of time, they will not return to Mexico: "A lot of people feel that they're going back to Mexico. ... The ones that are single don't want to adapt. But in the majority of cases, once you're here a few years, like more than 10 , then you're here for good. It takes people a while to come to that conclusion." Another articulates what he believes to be a tension between Mexican beliefs about returning to Mexico and the lived realities in Marshall: "Some of it might be too - although this is changing ... although this is more ... I've heard others tell me about it more than the Mexicans themselves, but some would say that the Mexicans, um, would still have in the back of their minds that they're going to work here and go back to Mexico.... So, the idea of being firmly rooted here isn't in their minds. But, I definitely see that changing because, once they have kids, you know it's not that easy to go back especially because they are illegal which means that you have to sneak back - you have to sneak to Mexico and then sneak back over here.... Um, the young men who are single don't mind doing that as much but once you have kids, it just gets to be too much." One narrator even went so far as to say that none of the Mexican immigrants are "leaving voluntarily," and that they would only leave when families were deported. 
Longstanding Marshall residents argue that Mexicans are staying in the U.S. primarily because of their families, and to a lesser extent because of their businesses. Mexicans, however, do not acknowledge plans to stay in the U.S. and cite family as the primary reason they plan to return to Mexico. We argue that these different characterizations of Mexicans' intentions, which lead to different narratives of Mexicans' future in Marshall, stem from different accounts of social identity. Marshall residents frequently characterize Mexicans as being moral, hardworking people who highly value family. According to Mexicans, Americans value work over all else, which frequently means not only being far from but also sacrificing one's family, culture, and ways of life for work. This is evident in many Mexicans' characterizations of their reasons for being in or staying in the U.S. (at least for now). One Mexican high school student told us that he got bored and went back to Mexico because in the U.S. there is no life, only work. Another said that in the U.S. he is always either at work or at home, whereas in Mexico he gets to be outside all the time and do lots of things.

Ironically, many Mexicans do in fact sacrifice family, culture, and way of life to come to the U.S. for work. However, by continuing to tell the narrative of their plans to return to Mexico, Mexicans can characterize themselves as people who do not share these values of work over all else, characterizing themselves instead as people who hold family as the most important thing. In contrast, longstanding Marshall residents' narratives, which articulate Mexicans as more permanent residents, allow them to characterize Mexicans as family-oriented. The Mexicans are staying in Marshall because of their families. Thus these opposed stories of Mexicans' future in Marshall both characterize Mexicans in the same way, but the central plots of the stories contradict each other. In order to construct these different stories, white and Mexican narrators mobilize different resources. Mexicans, for instance, voice Americans as slaves to their work in a way that would not be familiar to many Americans.

The stories about Mexicans' future in Marshall may also serve other functions. As we argued in our discussion of payday mugging narratives, longstanding Marshall residents often characterize Mexicans as victims, perhaps as a way of othering them. Longstanding residents' stories about Mexicans' future in Marshall also allow them to present Mexicans as victims. For example, while many of these longer-standing residents say that Mexicans are staying because they have families and they want a better life for their children, they also note that, if immigrants are undocumented, even if their kids go to school and do well they still have no future because they can't go to college. Much as we described with payday mugging narratives, Mexicans' versions of this story do not victimize Mexicans in the same way. Mexicans do explain that many young immigrants have limited educational opportunities if they remain in the U.S., but they present this as more of a choice for work and the support of their families, as opposed to an act of victimization. White narrators also 
consistently claim that Mexicans think of Mexico as "home." While the word "home" (or its Spanish-language equivalent) does not appear in Mexican narratives about Mexico, it is pervasive in non-Mexicans' narratives about Mexicans' desire to return to Mexico or their inability to do so. This allows non-Mexican residents to "other" Mexicans - acknowledging them as residents of their community but not seeing them as truly belonging.

If we were to explain these narratives of town history exclusively in terms of "macro" and "micro," we might focus on widely circulating stereotypes of immigrants and their instantiation in the stories. This would capture some of what is happening, but it would miss the change in longstanding residents' narratives over the past decade and the emerging contradiction between these and Mexican immigrants' own narratives of their future in Marshall. As the size and composition of this Mexican immigrant community changes rapidly, at this historical moment, residents' construals of one another shift. Some of these shifts involve stereotypes that are more local to this community - for example, the fact that many Italian Americans identify more closely with Mexican immigrants than your average American - and which would be missed by a "macro-level" account. If we want to account for these narratives as they actually occur in this setting, we must move beyond macro-level factors to consider changes that occur over shorter timescales. We must also continue to follow the narratives across communities, exploring how narrators in divergent social domains position themselves and others in sometimes-distinctive ways.

\section{Conclusions}

As Mexicans have moved to Marshall in large numbers over the past decade, they have presented a symbolic challenge to longstanding residents. These residents are trying to make sense of who the newcomers are and why they have come - a project of social identification. Immigrants are making sense of their new neighbors at the same time, and the groups' construals influence each other, at the same time as the demographic facts are changing and various models of identity are becoming salient locally and nationally. The social identification of Mexican immigrants is made more complex by the relative newness of Marshall's Mexican population. Since the town did not have Mexican residents until recently, there is more flexibility in models of and behaviors toward newcomers than one might find in regions of longstanding Latino settlement. Long time residents and newcomers use narratives, among other means, to communicate their emerging characterizations of each other.

We have argued that these processes of social identification in Marshall cannot be explained simply in terms of "macro-level" models and structures, coupled with "micro-level" actions and events. Constraints certainly exist, and 
institutionalized structures play a role in the social identities available to Mexican immigrants. Likewise, new ideas and practices emerge, and a full account must acknowledge this. But constraint and emergence are not located primarily at two scales. Organization at several scales is necessary to explain the patterns of social identification in Marshall and elsewhere. For example, some local features of the situation - neither micro nor macro - are essential. The presence of many Italian immigrants in this town matters, as they are often more sympathetic to Mexicans and introduce their own histories as resources for identifying immigrants. And the Mexican community is changing rapidly, shifting from bachelors to families, with corresponding shifts in the demographics of Mexican children in the schools. We must also move beyond discrete speech events to study trajectories of linked events, as in the narrative chains across which stories and related social identifications move. Macro and micro can be useful abstractions in some cases, but they do not suffice as an approach to understanding human phenomena.

\section{References}

Agha, Asif. (2007). Language and social relations. New York: Cambridge University Press.

Agha, Asif., \& Wortham, Stanton (Eds.). (2005). Discourse across speech-events: Intertextuality and interdiscursivity in social life. A Special issue of Journal of Linguistic Anthropology, 15(1).

Bakhtin, Mikhail. (1935/1981). The Dialogic Imagination. Austin: University of Texas Press.

Bateson, Gregory. (1972). Steps to an Ecology of Mind. Chicago: University of Chicago Press.

Bowles, Samuel, \& Gintis, Herbert. (1977). Schooling in capitalist America. New York: Basic Books.

DeFina, Anna, Schiffrin, Deborah, \& Bamberg, Michael. (2006). Discourse and Identity. Cambridge: Cambridge University Press.

DeGenova, Nicholas, \& Ramos-Zayas, Ana. (2003). Latino Crossings: Mexicans, Puerto Ricans, and the Politics of Race and Citizenship. New York: Taylor and Francis.

Duranti, Alessandro \& Goodwin, Charles. (1992). Rethinking context: Language as an interactive phenomenon. Cambridge, MA: Cambridge University Press.

Erickson, Frederick, \& Schultz, Jeff. (1982). Counselor as Gatekeeper: Social Interaction in Interviews. New York: Academic Press.

Giddens, Anthony. (1976). New rules of sociological method. New York: Basic Books.

Heath, Shirley. (1983). Ways with words: Language, life, and work in communities and classrooms. New York: Cambridge University Press.

Hymes, Dell. (1964). Introduction: Toward ethnographies of communication. American Anthropologist, 66, 1-34.

Krupa, Christopher. (2009). Histories in Red: Ways of Seeing Lynching in Ecuador. American Ethnologist, 36: 20-39.

Latour, Bruno. (2005). Reassembling the social. New York: Oxford University Press.

Lemke, Jay. (2000). Across the scales of time. Mind, Culture, and Activity, 7, 273-290.

Lempert, Michael. (in press). Interaction rescaled: How monastic debate became a diasporic pedagogy. Anthropology \& Education Quarterly.

Link, Holly, Lipinoga, Sarah, Allard, Elaine, Wortham, Stanton \& Mortimer, Katherine. (in press). Heterogeneous ideologies of Mexican immigrant language. Linguistics \& Education. 


\section{Stanton Wortham and Catherine Rhodes}

Massey, Douglas \& Sánchez, Magaly. (2010). Brokered Boundaries: Creating Immigrant Identity in Anti-Immigrant Times. New York: Russell Sage Foundation.

Michel, Alexandra \& Wortham, Stanton. (2009). Bullish on uncertainty: How organizational cultures transform participants. New York: Cambridge University Press.

Mortimer, Katherine, Wortham, Stanton \& Allard, Elaine. (2010). Helping immigrants identify as "university-bound students": Unexpected difficulties in teaching the hidden curriculum. Revista de Educación, 353, 107-128.

Ochs, Elinor, Schegloff, Emanuel \& Thompson, Sandra (Eds). (1996). Interaction and grammar. Cambridge: Cambridge University Press.

Pew Hispanic Center. (2011). The Mexican-American Boom: Births Overtake Immigration. Washington, D.C.: Pew Hispanic Center. Accessed 11/05/11: http://pewhispanic.org/files/reports/144. pdf.

Philips, Susan. (1983). The invisible culture: Communication in classroom and community on the Warm Springs Indian Reservation. Prospect Heights, IL: Waveland Press.

Postone, Moishe. (1993). Time, labor and social domination. New York: Cambridge University Press.

Rogers, Rebecca. (2003). A Critical Discourse Analysis of Family Literacy Practices: Power In and Out of Print. Mahwah, NJ: Lawrence Erlbaum Associates.

Rymes, Betsy. (2011). Deference, denial, and beyond: A repertoire approach to mass media and schooling. Review of Research in Education, 35, 208-238.

Sawyer, Keith. (2003). Improvised dialogues: Emergence and creativity in conversation. Westport, CT: Greenwood.

Schegloff, Emanuel. (2007). Sequence organization in interaction: A primer in conversation analysis, Vol. 1. Cambridge: Cambridge University Press.

Schieffelin, Bambi \& Ochs, Elinor. (Eds.) (1986). Language socialization across cultures. New York: Cambridge University Press.

Shotter, John. (1993). Cultural politics of everyday life. Toronto: University of Toronto.

Silverstein, Michael. (1992). The indeterminacy of contextualization: When is enough enough? In, DiLuzio, Aldo \& Auer, Peter (Eds.), The contextualization of language (pp. 55-75). Amsterdam: John Benjamins.

Spitulnik, Debra. (1996). The Social Circulation of Media Discourse and the Mediation of Communities. Journal of Linguistic Anthropology, 6, 161-187.

Suárez-Orozco, M. (1998). State terrors: Immigrants and refugees in the post-national space. In, Zou, Yali \& Trueba, Enrique T. (Eds.), Ethnic Identity and Power: Cultural Contexts of Political Action in School and Society (pp. 283-319). Albany, NY: State University of New York Press.

Urban, Greg. (1996). Metaphysical community. Austin, TX: University of Texas Press.

Urban, Greg. (2001). Metaculture: How culture moves through the world. Minneapolis, MN: University of Minnesota Press.

U.S. Census Bureau. (2011). American Fact Finder: US Census 1990, Tables P001, P006, P008 and P009 (Summary Table File 1); US Census 2000, Tables P1 and P8 (Summary File 1); US Census 2010, Table P2, Hispanic or Latino and Not by Race. Accessed 11/05/11: http:// factfinder2.census.gov/.

Van Dijk, Teun. (1987). Communicating Racism: Ethnic Prejudice in Thought and Talk. Newbury Park, CA: Sage.

Wertsch, James. (2002). Voices of collective remembering. New York: Cambridge University Press.

Wortham, Stanton. (2001). Narratives in Action: A Strategy for Research and Analysis. New York: Teachers College Press.

Wortham, Stanton. (2005). Socialization beyond the speech event. Journal of Linguistic Anthropology, 15, 95-112. 
Wortham, Stanton. (2006). Learning identity. New York: Cambridge University Press.

Wortham, Stanton (Ed.). (in press). Beyond Macro and Micro in the Linguistic Anthropology of Education. A special issue of Anthropology \& Education Quarterly.

Wortham, Stanton, Allard, Elaine, Lee, Kathy, \& Mortimer, Katherine. (2011). Racialization in Payday Mugging Narratives. Journal of Linguistic Anthropology, 21, E56-E75.

Wortham, Stanton, Mortimer, Katherine, \& Allard, Elaine. (2009). Mexicans as model minorities in the New Latino Diaspora. Anthropology \& Education Quarterly, 40, 388-404.

Wortham, Stanton, Mortimer, Katherine, \& Allard, Elaine. (2011). Homies in the New Latino Diaspora. Language \& Communication, 31, 191-202.

Wortham, Stanton, Mortimer, Katherine, Lee, Kathy, Allard, Elaine, \& White, Kimberly. (2011). Interviews as Interactional Data. Language in Society, 40, 39-50.

Stanton Wortham is the Judy and Howard Berkowitz Professor of Education at the University of Pennsylvania Graduate School of Education. His books Acting out participant examples in the classroom, Linguistic anthropology of education and Learning identity: The joint emergence of social identification and academic learning, together with various articles and chapters, explore interrelations between the official curriculum and covert interactional patterns in classroom discourse. He has also studied interactional positioning in media discourse and autobiographical narrative, and he has developed methodological techniques for analyzing narrative, media and other everyday discourse. 〈stantonw@upenn.edu〉

Catherine R. Rhodes is a joint Ph.D. candidate in the Education, Culture, and Society program in the Graduate School of Education and in Linguistic Anthropology in the Anthropology Department at the University of Pennsylvania. She holds an M.A. in the Social Sciences from the University of Chicago and a B.A. in Latin American Studies from the University of North Carolina at Chapel Hill. Her research interests include semiotics, language diversity and cognition, bi- and multilingualism, social identification, discursive self-making, narrative, and discourse analysis. 〈rhodesc@gse.upenn.edu〉 

Copyright of Applied Linguistics Review is the property of De Gruyter and its content may not be copied or emailed to multiple sites or posted to a listserv without the copyright holder's express written permission. However, users may print, download, or email articles for individual use. 